\title{
Introduction: Writing and Reading About Medieval Disfigurement
}

"Probably from a social point of view, a simple facial disfigurement is the worst disability of all-the quickly-suppressed flicker of revulsion is, I am certain, quite shattering." "This statement, made by a person reflecting on his own social challenges living as a muscular dystrophy sufferer in in the 1960s, expresses succinctly the horror that facial disfigurement holds for modern observers, and its perceived place in the spectrum of social disability. Whilst modern medicine has in the intervening five decades largely perfected the process of "improving" the appearance of the disfigured face through prosthetics, surgery, skin grafts and sophisticated cosmetics, the aesthetic and technical genius of some modern medical prosthetics units is often up against deep-rooted psychological damage in the subject, which finds its expression in dissatisfaction with the "new" facial features, and may even lead to outright rejection. ${ }^{2}$ The ingrained sense of disgust that facial damage is said to provoke in its victims and observers alike is even the subject of psychological studies, where the assumption that an impaired face will evoke such a response is taken as a given fact. ${ }^{3}$ William Ian Miller puts it succinctly: "There are few things that are more unnerving and disgust evoking than our partibility... severed hands, ears, heads, gouged eyes...Severability is unnerving no matter what part is being detached." 4 The high-profile, modern cases of individuals who have "fought back" from severe facial damage, whether through burns, acid attacks or mutilation, have gone some way toward challenging such attitudes; and as historians reflect on the centenary of the destruction and loss of life inflicted in World War I, the facial disfigurement of returning soldiers from two World

(C) The Author(s) 2017

P. Skinner, Living with Disfigurement in Early Medieval Europe, DOI 10.1057/978-1-137-54439-1_1 
Wars has featured in a number of research projects, interested not only in the human story of such men, but in the early attempts at surgical and prosthetic intervention. ${ }^{5}$ As Suzannah Biernoff comments, "being human is an aesthetic matter as well as a biological one."

All of this work, however, and the very few studies that have sought to trace the history of aesthetic or cosmetic surgery, start from the assumption that acquired facial disfigurement is and was, universally, a stigmatizing-worse, a disgusting — condition. ${ }^{7}$ Reading early accounts such as Ward Muir's The Happy Hospital, published in 1917, it is hard to avoid the sense of horror that accompanies the loss of facial features. ${ }^{8}$ The explosion of work in the 1960s on stigma, social identity theory and deviance in the social sciences, including the influential studies of Erving Goffman and Henry Tajfel but echoing the earlier work of Durkheim on anomie contributed toward reinforcing the apparent marginalization of the impaired or disfigured. Earlier generations of historians, whilst stimulated in their research questions by sociological and anthropological models, were rather too accepting of the assumptions underlying such studies, assumptions that they themselves might share. Thus physical difference, in all of its manifestations, was implicitly labeled as abnormal almost before the study began. The "impairment"-disfiguring injury—led to the "disability"-society's response to the injured face. ${ }^{10}$ This owes much to the modern discourse within the history of medicine and surgery of the "progress" made in those fields, the ever-increasing ability of the profession to "fix" faces and bodies, and restore the individual to some kind of "normal" life. Thus both those with congenital conditions, such as cleft lip or palate, as well as those whose disfigurement is acquired during their life course, are subject (or subjected) to surgical repair, and even [physically] nonthreatening conditions such as birthmarks are lasered out of existence. Yet surgery can itself also disfigure a person, particularly in the case of excision of cancerous tumors. This in turn leads to further intervention to repair the damage, introducing prosthetic replacements for the absent flesh. ${ }^{11}$

The early Middle Ages have not fared well within this teleological framework of surgical and medical progress: it is telling that studies of later medieval medical and surgical texts have highlighted their "rational" nature, and through such apologetic the authors of these studies have revealed their own attachment to post-Enlightenment, scientific approaches to medicine. ${ }^{12}$ In terms of surgical treatments for the damaged face, recent attention has lighted upon texts from the early modern period, proposing ways to replace lost or damaged noses. ${ }^{13}$ One result 
of this has been the under-representation of the earlier Middle Ages in histories of medicine, and an over-emphasis on the power of the written medical theory at the expense of work on the social history of medicine and practice in this period. ${ }^{14}$

This book seeks to address such omissions through examining social and medical responses to the disfigured face in early medieval Europe, arguing that head and facial injuries can offer a new contribution to the history of early medieval medicine, as well as offering a new route into exploring the language of violence and social interactions. In its early stages, the research underpinning the book was, it is fair to say, very much shaped by some of the assumptions outlined above-that medieval people would view disfigurement with at best ambivalence and at worst disgust. Yet this assumption has never been effectively tested within previous historiography. Despite the prevalence of warfare and violence in early medieval society, and a veritable industry studying it (largely, if not exclusively, focusing on the later Middle Ages), ${ }^{15}$ there has in fact been very little attention paid to the subject of head wounds and facial damage in the course of war and/or punitive justice. ${ }^{16}$ The impact of acquired disfigurement, for the individual, and for her or his family and community, is barely registered, and only recently has there been any attempt to explore the question of how damaged tissue and bone might be treated medically or surgically before the thirteenth century. ${ }^{17}$ Moreover, whilst the body as a site of physical and metaphorical meaning has attracted the attention of literary scholars and historians of gender since the 1980s, to the extent that it is now a relatively mature field of study and even features work on the head, the specific, and to my mind obvious, role of the face in medieval social interactions has barely been addressed. ${ }^{18}$ Yet one of the pioneers of that field, Miri Rubin, long ago pointed out that examining parts of the body could give an insight into how the whole body functioned or was understood, especially if those parts were in pain. ${ }^{19}$ The somewhat marginal field of physiognomy, the practice of determining character traits though the scrutiny of facial features, is largely overlooked in studies of the early Middle Ages, not least because it was not heavily represented in Christian European texts or discourse in the period under review. It was nevertheless recognized as a practice in the early medieval Muslim regions of Europe, and would enjoy more prominence from the thirteenth century as physiognomic texts were circulated with medical works, and new treatises were compiled with royal patronage. Some work, therefore, is now being done on the transmission of such texts between antiquity and the Middle Ages. ${ }^{20}$ 
In terms of a social history of facial disfigurement, however, newer fields of medieval studies are highlighting the lives of hitherto unnoticed groups, and offering potential approaches to the topic. A growing body of work exploring medieval impairment and disability touches upon the sensory impairments resulting from political and judicial mutilations of the head and face, and studies of specific groups of people with physical impairments in the medieval past are increasingly being published. ${ }^{21}$ The now well-established field of research into the medieval emotions, utilizing both medieval descriptions and modern psychoanalysis, and owing much to the work of Norbert Elias, has to some extent legitimized the desire on the part of historians to speculate on the psychological impact of life events on medieval people, as well as to analyze the role of specific emotional states within ritual behaviors. ${ }^{22}$ The use of non-medical texts from the centuries before 1200 is beginning to reveal how medical practitioners may have been identified and valued in early medieval society. ${ }^{23}$ The field of osteoarchaeology, and increasing samples of material being analyzed from early medieval contexts, is demonstrating that some surgical procedures known in the texts were actually being carried out, and that the recipients of such treatment (and even some who did not get such care) might well survive quite serious head trauma. ${ }^{24}$ And visual representations of medieval faces are increasingly coming under scrutiny not just by art historians, but also cultural historians intrigued by representations that were not quite portraits, but whose elements (in particular facial and other hair) were clearly imbued with almost supernatural meanings. ${ }^{25}$

Yet facial disfigurement remains a poorly-understood topic in medieval history, partly because it relates to all of these sub-fields of historical enquiry, and yet belongs wholly in none of them. Combining the insights of historians of disability, forensic archaeologists, scholars of literary and visual culture and the histories of premodern medical practice with a renewed interrogation of early medieval primary sources, it is possible to explore several key questions:

- How prevalent was acquired cranio-facial disfigurement in early medieval Europe (including the Byzantine empire and Mediterranean littoral)?

- How did it occur and why?

- In what contexts, and with what kinds of language, did it come to be recorded?

- How did contemporaries treat the disfigured face (medically and socially)? 
The aims of this book are to document how acquired disfigurement is recorded across different geographical and chronological contexts; to examine how the genre of text affects the record of injury and responses to it; to determine the specific medical and health implications that such punishments had for the individual and her/his community; to compare the practical knowledge available in different locations across time to deal with the aftercare of such injury, and ask whether it was applied.

Geographically, the range of the study is wide: sources from Ireland, the Byzantine Empire and most (but regrettably not all) regions in between are mined for examples of disfigured men and women (whether actual, or imagined), and account is taken of regional and linguistic difference, the possibilities of transmission of disfiguring practices, and the potential medical care available at the point of injury. Chronologically, the study ranges from late antiquity (often as reported in early medieval sources) to the pivotal twelfth century. The latter functions as both end point for logistical reasons (the study had to stop somewhere) but also as a point when, besides the legal and intellectual revolution known to older scholarship as the twelfth-century Renaissance, the political landscape of Europe was becoming increasingly defined, and claims to authority (in particular the right to define social outsiders and inflict mutilating punishment) were being negotiated in light of western Europe's increasing interactions with both Byzantine and Muslim neighbors. The impact on the physically impaired of the formation of the "persecuting society" has not yet been fully worked out, except in economic terms, ${ }^{26}$ but it seems that there was a heightened awareness, at the end of the period under discussion, of the messages encoded in damaged facial features. Insofar as the source itself was interested in such matters, an attempt is made, therefore, to explore the "before" and "after" of selected cases of acquired disfigurement, and to situate them in the broader social norms of early medieval societies.

\section{Congenital vs. Acquired Conditions}

It is important at the outset to define the parameters of the study, and in particular to explain its focus on acquired, as opposed to congenital, disfigurement. Within medieval society, the birth of a child with a congenital impairment might provoke a series of responses: it might not be cared for as well, in the hope of a swift and early death; its birth might be interpreted as a punishment from God for a perceived misdemeanor by the mother, or both parents; it might be abandoned, or made a "gift" to the church; or it might be nurtured, and allowed its place in the family 
(it is possible to imagine that a couple who had already had healthy children might respond more positively, whilst an impaired firstborn might be viewed rather differently). ${ }^{27}$ Burdened by Philippe Ariès' controversial theory that parents could not afford to invest emotionally in their children due to the high child mortality rate in the Middle Ages, subsequent studies challenging his thesis have rather overlooked the lot of the physically impaired child in their championing of children as a group. ${ }^{28}$ The exception to this statement has been the work of archaeologists such as Sally Crawford, who argue that impaired children could be nurtured, and that isolated examples of adaptive technology—such as a specially-shaped drinking cup for a child with a cleft lip or palate-are proof of this. ${ }^{29}$ Of course, it is dangerous to generalize on single examples, but the survival of such children, and their integration into their community, might ultimately depend not on attitudes to impairment, but on the relative social status of their parents and wider family (one thinks of the numerous impairments encoded in the epithets accorded to the Carolingian royal dynasty, for instance). Either way, as they grew up their impairment was a constant feature, something that God had shaped, and their presence in the community would have become commonplace, something people were used to, and threatened only by outsiders or a change in their own circumstances (one wonders how far an extended family would step in on the death of parents, for instance). They may, of course, never have grown up, and so their difference did not impact upon their acquisition (or not) of social adulthood. This at least is the conclusion reached in a recent archaeological report, which sought reasons for the undifferentiated burial of an Anglo-Saxon child with a severely deformed jawbone, the result of fibrous dysplasia. ${ }^{30}$

By contrast, the vast majority of references to acquired disfigurement in early medieval sources present it as a sudden transformation resulting from interpersonal or group violence among human beings rather than the result of a supernatural intervention, with the exception of hagiographic texts where a saint suddenly punishes a transgressor for perceived or actual sins. ${ }^{31}$ The disfigurement was inflicted on one person (or group) by another, whether or not such actions were legal or moral. Disfigurement often took its place alongside other types of physical mutilation, and could be combined with them, although it is difficult to trace any consistent continuum from one disfiguring act to another. ${ }^{32}$ Moreover, these episodes occurred entirely during adulthood, ${ }^{33}$ and thus had the potential to destroy or severely damage a pre-existing, and established, social identity. It is this 
sudden change, and its impact both on the person and her/his community, that is of particular interest, since in the words of Valentin Groebner, the facially-mutilated in later medieval Europe (especially those whose noses were cut off) became Ungestalt-hideous, faceless, non-persons. ${ }^{34}$ The term functions as a noun and an adjective, so hideousness, non-personness, exist as medieval concepts in the mainly later medieval, German, urban cases he studies. ${ }^{35}$ Groebner was chiefly concerned with the visual impact of such violence, and his work largely reinforces long-held stereotypes about the cruelty and violence of the later Middle Ages, but to a great extent it ignores the earlier period, not least because the judicial world in which his subjects lived had been profoundly altered by the resurgence of Roman legal studies in the twelfth and thirteenth centuries, with their emphasis on punitive, rather than compensatory, justice. Groebner's work, however, pointed up the need for more work to be done on the face as a specific site of identity and violence, a need that the present study tries to address.

Lying between the two fields of congenital disfigurement and its sudden acquisition during adulthood is the progressive disfigurement brought about by disease, in particular leprosy. ${ }^{36}$ Certainly lepromatous leprosy, the most serious form of the disease, was a disfiguring condition, and an anecdote in the life of the twelfth-century holy woman Oda of Brabant suggests how quickly the signs of leprosy could be identified (in this case, wrongly) and lead to social exclusion. ${ }^{37}$ But the disfigurement caused by leprosy, and indeed other skin and fleshly conditions, was not inflicted by others, but interpreted as both a curse as well as a gift from God. ${ }^{38}$ Some saints' lives even have the saint praying to be afflicted with the disease as part of their journey toward true humility. ${ }^{39}$ Lepers were a special case in that they were increasingly excluded and housed in separate spaces from the medieval community, but it was their contagious disease, rather than its visible results, that was the reason. Their condition was one to be pitied, and offered the opportunity for the well to provide charity to this special group. Whilst it is entirely possible that some people with disfigurements were mistaken for lepers, the analytical categories of lepers and disfigured people have far more differences than analogies.

\section{WHAT IS "DisFiguREMENT"?}

What, though, does that word "disfigurement" actually mean? The root of the English word is the Latin figura, meaning shape or form, so a literal translation from English into Latin would give us the sense 


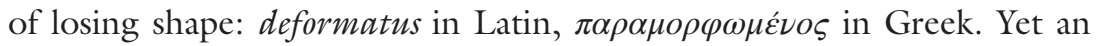
electronic search for the Latin term in a major source collection such as the Monumenta Germaniae Historica reveals only 21 occurrences of this root, most of which refer to abstract deformation of morals or institutions such as the Church. A few refer to deformed body parts, but none refer to the face..$^{40}$ "Misshapen," therefore, does not quite seem to capture the sense of "disfigurement" we're looking for here, and it is difficult to find, in the many cases I have gathered, any real equivalent to the English term. "Disfigurare" in the seventh-century Lombard laws refers to unspecified damage caused to a stolen horse, whilst "defigurare" seems to indicate disguise, as applied to the treacherous Eustace the monk, in the chronicles of Matthew Paris recounting the battle of Sandwich in 1217.41 The same difficulty is true of the few Greek examples: what Freshfield translates as "disfigured" in his presentation of a later Byzantine law on injuring the beard is in fact rendered as $\alpha \pi \sigma \sigma \varphi \alpha \lambda \tau \iota \omega \sigma \alpha \varsigma$ in Von Lingenthal's edition, and translated by the latter as "interemerit" or "destroyed." 42

The Latin "mutilatio" and variants occur far more frequently (featuring multiply, for example, in over eighty MGH volumes), but only a small minority of these references deal with injury to the face, and the term far more frequently indicates loss of hands or limbs or, again, injury to institutions such as the Church, the kingdom, or a person's moral wellbeing. Searching on a specific term, of course, inevitably misses out all the facial injuries that are not referred to as "mutilation," including the lengthy tariff lists in early medieval law codes, explored later.

If language constitutes reality, does this lack of a stable term for disfigurement (in the MGH sample at least) mean that medieval society did not conceptualize facial appearance in this way? Does searching for disfigurement ill-advisedly project a modern idea onto a random selection of damaged medieval faces? To answer the first question: there is plenty of evidence for damaged faces being "read" by contemporaries, and appearance being associated with honor or a lack of it. Early medieval legal compilations spoke of the shame of being injured (although "injury" here takes on a wider range of meanings than simply the physical, as we shall see). That the tenth-century compilation of Bald's Leechbooks in England took the trouble to include a surgical procedure for hare lip, and featured remedies for blotchy faces, suggests that (in theory at least) faces mattered. ${ }^{43}$ To tackle the second point, the application of modern questions and concepts is an everyday part of medieval history, whether conscious or not, and several scholars have explicitly 
tried to connect medieval and modern manifestations of social behaviors in order to better understand both. ${ }^{44} \mathrm{~A}$ strong proponent of continuity is William Ian Miller, who argues that "our disgust maintains features of its medieval and early modern avatars," a contention that this book explicitly explores, and that historians are more confident in identifying difference in the past than sameness. ${ }^{45} \mathrm{~A}$ recent criticism of medical history as "moribund" also challenges scholars of more distant pasts to engage critically with modern discourses on their subject, and to recognize that reconstructing the past of minority and marginalized groups is a political act, forcing us to face our own prejudices and examine their possible origins. ${ }^{46}$

Returning to the word "figura," it is useful in this context to use the modern Italian usage, which refers not only to physical shape, but also, in the phrase "fare una bella/brutta figura," to the image of self (good or ugly) that is projected to the world. The potential for a facial or head injury to shame or stigmatize the individual was, it seems, entirely dependent on the circumstances surrounding that injury: stigma is always contingent. Chris Mounsey has coined the term "variability" to express discontent with the binary opposite of able-bodied/disabled, and this is a useful concept to keep in mind when exploring disfigurement: one person's disabling injuries, in medieval culture, might be another person's badge of honor, depending on what both did for a living or how both responded to their new faces. ${ }^{47}$ In this book, the range of facial conditions considered as possible "disfigurements" ranges from common injuries such as scratches and broken noses to severe, potentially fatal head injuries with the capacity to leave permanent scarring and/or cognitive impairment. The facial "frame," that is, the hair and the ears, are also considered part of this visual compendium, and so "disfigurement" is used as shorthand for a broad and mutable range of conditions. Yet texts relating incidents of early medieval disfigurement present a much less fluid picture: whether inflicted legally or not, deliberately or not, disfigurement was intended to be visible, and/or perceived to be humiliating. ${ }^{48}$ It also falls into a number of repeating categories: shaving and hair-cutting, surface burning and branding, the removal of all or part of a facial feature (nose, eyes, ears), injury by blade, and injury by projectile. The very few cases that fall outside these categories are, by definition, written up as exceptional. The authors of texts detailing the very few exceptions, discussed later in the book, took great pains to justify why a disfiguring injury should not be read negatively. ${ }^{49}$ 
The underlying message is the same: the disfigured potentially formed what anthropologists would term an "out-group"—and their stigma might be overlain with a heavy veneer of moral opprobrium - these people are disfigured, our authors argue, because of some fault of their own or others. This contention will be explored further in Chapter 4. Yet unlike other stigmatized medieval groups, the disfigured do not feature in early medieval texts as a group or category - in contrast to the blind, the lame, the poor or the leprous, for instance. This has contributed to their relative invisibility in scholarly studies to date, despite the sheer quantity of examples (set out chronologically in Appendices 1 and 2, below) in texts of the period.

\section{Sources ANd Resources}

So where do we capture the "flicker of revulsion" in medieval texts? Does it even exist? The study examines a wide range of sources in order to trace moments of acquired disfigurement, the contexts within which they were reported, and the language used to report both perpetrators and victims. These include law codes, early and later; chronicles and annals; hagiographic texts; medical texts; archaeological remains; and iconography. Whilst the occasional example will be drawn from the works of the medieval literary imagination (one cannot explore facial disfigurement and ignore the riches of early Irish myths, or tales such as Marie de France's Bisclavret, for example), such texts are discussed at the point of citation, and so are not analyzed collectively here.

\section{Law Codes}

Western Europe in the early Middle Ages was a patchwork of formative polities, whether the multiple small kingdoms of early Irish society, the very similar territories surrounding trefi in Wales, or the successor states (duchies, kingdoms and principalities) to Roman rule in England and the continent. Byzantium, by contrast, was a fully-formed empire, albeit one with wildly-fluctuating borders between 500 and 1200CE. A common thread running through all of their histories, however, was the urge to legislate, or to set down in writing the laws of their region, or to revise existing codes. This was not-or at least not entirely-a product of the conversion to Christianity, and some early laws have clear signs of incorporating older practices within the overarching rhetoric of peace brought about by compensation for injury. 
The social realities of civil life in the early medieval West and Byzantium, and the often intricately detailed frameworks for that civil society set out by numerous laws rarely intersected, however. Laws were always a work in progress, designed more to reflect the aspirations of the ruler to authority vested in his/her own body and/or conferred by God than to actively regulate every aspect of her/his subjects' lives. It would be all too easy to dismiss the law as essentially the intellectual, text-based activity of court cultures, concerned to project a certain image of rulership whose pedigree stretched back to the Roman Empire, but unenforceable and largely unenforced. The continuous process of excerpting, reordering and adding to the legal corpus made visible by generations of legal historians certainly does not convey much sense of justice in action.

Indeed, law codes may not even represent contemporary attitudes toward violence or aspire to its control. In a series of articles and his last book, Patrick Wormald raised the important question of the purpose of medieval legislative texts, particularly their copying and preservation. For the Frankish kings, he suggested, recopying and preserving the ancient Salic laws was about reinforcing Frankish identity, and co-existed with supplemental law-giving in the form of capitularies which often seemed to respond to specific cases. ${ }^{50}$ Such practices were not confined to the Frankish world, of course; Wormald argued that the "ideological climate of King Alfred's Wessex belonged to the Carolingian zone," and that England was by no means isolated from the intellectual currents of the continent in the tenth and eleventh centuries. Successive kings of England (or, rather, their clergy, such as Wulfstan of York) revised and renewed the laws of their predecessors. ${ }^{51}$ This urge to revise and add to the law, ultimately deriving from Roman models and continued as well in the kingdoms within Wormald's "olive belt," that is, southern Europe, was particularly (and unsurprisingly) demonstrated by Byzantine emperors as well, who issued Novels or new laws to add to the old, rather than attempting new codifications. ${ }^{52}$ Each new ruler seems to have been unable to resist the temptation to tinker, amend and add laws that "seemed good," as numerous preambles to extant law codes make clear.

Yet these introductions, setting out the why and wherefore of the new code, were of course as much a rhetorical performance of kingliness or imperial dignity as they were representative of an actual ruler's aspirations. The ideological value of setting up the ruler as legislator exceeded the practical impact of the laws themselves. In an important recent article, Geoffrey Koziol has used capitulary evidence from the end of 
Charlemagne's reign in the early 800 s to demonstrate that not only could early medieval central government, such as it was, not regulate its citizens' lives, it did not seek to do so, but set up models of right behavior, effectively asking the people to discipline themselves, rather than expect state intervention. ${ }^{53}$ Charlemagne and his successors, however, still engaged in the work of codifying and re-issuing Frankish laws and, as the Carolingian empire expanded, newly-subject peoples were also "given" written codes of law by their Frankish rulers.

Turning to the content of laws, therefore, we need to keep in mind this ideological frame, even if subsequent writers have argued for a more nuanced approach than Wormald's. ${ }^{54}$ In the laws of early medieval Western European kingdoms, it is most obvious in extended, and almost ubiquitous, sections on the body: corporeal injuries down to specific teeth in the mouth were tariffed with specific fines, conveying the sense of a pervasive justice system which literally could reach into every orifice..$^{55}$ Lengthy tariff lists set out what payment in money or value of chattels (or female slaves) was due to the victim of an assault, and this was dependent not only on which part of the body had been injured, but also how seriously (did the wound heal?) and often taking into account the social status of the victim as well (male or female, slave or free).

The close attention to the body paid in the early medieval law codes has already attracted the attention of medieval historians. ${ }^{56}$ Textual similarities between different codes, however, such as a memorable cluster judging the size of bones retrieved from a skull injury by the sound they made in various receptacles, caution against their literal reading. ${ }^{57}$ These parallels, occurring in laws from Francia, Italy, Frisia and Wales, suggest that borrowings took place over space and time. Either way, they provide a substantial body of evidence for concern with the head and face in early medieval culture. For our purposes, the value of using these legal sources lies not so much the question of whether such laws were ever put into practice, as in the ideological framing of the face and body that they reveal.

\section{Chronicles and Annals}

Not surprisingly, many of the contemporary and later reports of deliberate disfigurement in chronicles and annals (accidents being something of a rarity in the texts) appear to share the ideals and moral frameworks laid out in the laws. Blows to the face, whether or not disfiguring, seem 
to have been serious enough to merit recording, especially if the victim was of high status. ${ }^{58}$ Some of their evidence has been cited in previous works dealing with cruelty and atrocity in medieval society, or in studies of extreme emotions such as anger. Some, such as the tit-for-tat disfiguring atrocities committed during the later Albigensian crusade, have become emblematic of that entire enterprise, obscuring the less sensational stories of the spread of the friars and the imposition of French royal power in the region. ${ }^{59}$ Often, such episodes have been read literally to reinforce stereotypes of medieval society as extremely and unrelentingly violent, rather than being read with a critical eye as to what the author's purpose was in constructing his (or occasionally, her) report. Keeping in mind that most reporters were working within a clerical or even monastic environment, extreme violence is used, more often than not, to point up the lack of judgment, or downright cruelty, of the perpetrator, and is written up by authors to evoke pity for the victim.

At the most extreme end of this spectrum of violence is a late, but emotive example reported by Rolandinus of Padua for the year 1259. Having captured the city of Friuli, Ezzelino da Romano:

$\ldots$ ordered, that the unfortunate people of Friuli, male and female, great and small, clerics and laypeople, and all of those cut down and injured, should bear the rage of Ezzelino throughout Lombardy and the March. It did not profit the innocent children that they had not sinned, rather, whilst the old and the young were exposed to a triple penalty, mutilated in their eyes, noses and feet, the infants and innocents suffered a quadruple penalty, for having lost their noses and feet at Ezzelino's order, they were blinded in their eyes and their genitals were cut off. This extreme cruelty was perpetrated by Ezzelino at the end of June in the aforementioned year of our Lord. ${ }^{60}$

Rolandinus makes it clear how his readers should react to his report-whatever the exact circumstances of Ezzelino's treatment of the Friulians, his cruelty is written in language evoking Herod's massacre of the innocents, and designed to provoke shock and revulsion. Already condemned as a heretic in a letter of Pope Alexander IV a year earlier, ${ }^{61}$ Ezzelino could be used by Rolandinus as an archetype of evil. Indeed, it might be argued that mass mutilation had become something of a generic plot device by the thirteenth century ${ }^{62}$ - the man capable of this, it is implied, is beyond redemption.

Whilst falling outside the period under review in this study, Rolandinus's passage is useful for pointing up the framework within which medieval 
chroniclers largely operated. His subtle evocation of a parallel between Ezzelino and Herod was a common trope, and often made explicitly by clerical writers to decry rulers as tyrants. ${ }^{63}$ Gregory of Tours, for instance, calls King Chilperic (d. 584) "the Nero and Herod of our time" for his cruelty in punishing crimes. ${ }^{64}$ Clerical authors, though, could and did draw upon a whole range of Old Testament exempla to frame their chronicles. Whilst some may protest their veracity or are sprinkled throughout with conscious references to their reliability, including references to authors consulted, records used and the oral reports of reliable witnesses, their writing was shaped by the generic, biblical frameworks visible in those same earlier works. As Guy Halsall comments, referring to reports of violence, "Neither writer nor reader expected the minutiae of what actually happened to bog down a written account, or to take precedence over the display of knowledge of classics, scripture or the writings of the Church Fathers (patristics). The 'True Law of History [lex vera historiae]' was moral, not empirical." 65 Antonella Liuzzo Scorpo and Jamie Wood concur that many narratives of violence were written in a "scriptural mode," offering ready-made rhetorical devices for description, but also a set of tropes around forgiveness and redemption. ${ }^{66}$

With regard to disfigurement, the Levitical ban on mutilated priestly bodies was never far from the mind, especially in reports of injured rulers or clergy. We shall meet numerous cases of rulers "removed" from power through facial mutilation and/or blinding, and a range of responses to such acts by our authors, running from the just punishment of a usurper or tyrant to a quasi-hagiographical martyrdom. Thietmar of Merseberg's early eleventh-century account of the blinding of Boleslav III of Bohemia (d. 1037), for example, lies on the former end of this spectrum. ${ }^{67}$ Moreover, whilst the "mark of Cain" does not appear to have been a reference point in accounts of disfigurement (the Bible is, after all, somewhat ambiguous about what the mark or sign was), its interpretation as sparing his life but thereafter identifying him as a murderer was an influential rationale in medieval justice schemata-a mark of infamy, rather than swift execution, conveyed the message of royal authority, and extended beyond murder to such offences as treason and theft. ${ }^{68}$

This common framework for the Christian texts under review is most apparent if we compare across centuries: Rolandinus's horror at Ezzelino the tyrant in the thirteenth century echoes almost perfectly Anna Komnena's twelfth-century depiction of the Norman Robert Guiscard (d.1086), or Amatus of Montecassino's account of the cruelty of Prince 
Gisulf II of Salerno (d.1077), and Gregory of Tours' condemnation of Merovingian kings who imposed mutilations unjustly in the sixth century. ${ }^{69}$ Facial disfigurement, as we shall see, was more often than not presented by chroniclers as a measure of the evil or lack of control of medieval rulers or their servants. ${ }^{70}$ Every episode, therefore, was highly ideological: it was used to think with, rather than being widely prevalent as a practice in medieval Europe and Byzantium. Those reports of actual harm, I suggest, need to be examined with an eye to the writer's purpose in reporting them, as none are without political or moralizing message, and some, like Rolandinus's account of Ezzelino, test the boundaries of credibility. It is not enough to take the descriptions of such violence as evidence that medieval society was driven by violent acts, and the terror evoked by multiple or group disfigurements should not lead us to the conclusion that all disfigurement was understood in this way. These are specific instances set out within pre-determined frameworks of good and evil, and deployed for specific purposes in the texts. If our writers had been interested in the phenomenon of disfigurement in and of itself, we should surely have more reports of accidents, or injuries caused by fire, one of the great hazards of medieval life, but until the advent of coroners' reports in later medieval Europe, we do not. Individuals with acquired disfigurements had to have a special story in order to be recorded at all; many cases to be considered were drawn from the social elite, for whom status trumped their newlydamaged features. The rest, if they existed in any substantial numbers, remain outsiders in that their lives and experiences - and the responses of others to their disfigurement-were not thought worth setting down in writing.

\section{Hagiographic Texts}

The exception to this statement regarding the visibility of disfigured people is the hagiographic genre, where some do appear in more than brief detail. Historians of medicine have long mined such texts as indicators (and, in earlier works, evidence) of medieval attitudes toward sickness and cure, ${ }^{71}$ and early work on medieval disability, too, plundered the rich sets of examples of impairment in medieval saints' lives to explore this theme. ${ }^{72}$ But what credence should we give to the punishments inflicted by saints that were targeted at the face? What are we to make of eyeballs popping out in the Book of Sainte Foy, for example? ${ }^{73}$ This seems a dangerous field to enter into if we are in search of the lived experience 
of victims of disfigurement - the supernatural nature of the punishments largely excludes them from consideration (just as I have excluded other conditions deriving, in medieval eyes, from the will of God). Hagiography does, however, shine a more direct light on the ideological frames that inform our supposedly reliable chroniclers; we might say that there is little to choose between them in terms of mindset. In building the case for this or that saint's holiness, hagiographic texts often tangentially incorporate important types of disfigurement that other sources omit. In the present study, hagiographic texts are used to inform our analysis of the ideology and rhetoric of disfigurement in three specific contexts.

The first is the Byzantine Empire during the two periods of iconoclasm, when a purge was decreed of all figurative icons as idolatrous. Hagiography of this period presents the stories of monks resisting the decree, and being punished with various atrocities targeted at their faces and bodies. The tortures seem chiefly to precede execution, but not always, suggesting that the punishments are exemplary and designed to be read and understood by those encountering the victims. As far as I am aware, however, there has not been any consideration of the apparent link between erasure of icons and erasure of facial features in the punishments of the iconodules (icon-supporters). This despite the fact that icons, like living faces, were understood as far more than an aesthetic image. ${ }^{74}$

The second context is the Anglo-Norman world of the eleventh and twelfth centuries, where saints are reported as repairing the damage of unjustly-inflicted mutilations. Strikingly, texts from this period echo the Byzantine examples in their motifs: tyrannical or misguided rule inflicting a terrible punishment, and the hagiographer explicitly criticizing that decision. Here, though, the saints put things right. Thus Thomas Becket from beyond the grave assisted Ailward of Westoning, restoring the man's eyesight and testicles after their mutilation, and the miracles of St Wulfstan of Worcester give a lengthy account of the mutilation, and subsequent cure by Wulfstan (d.1095), of Thomas of Elderfield, wrongly blinded and castrated in $1217 .{ }^{75}$ Both of these episodes are well-known and have been discussed in numerous contexts, particularly the sensationalism with which the mutilations themselves are presented: heightened language, the horror of Thomas of Elderfield's eyeballs and testicles being used as footballs. $^{76}$ Rather neglected, by contrast, is the careful and possibly equallysuspect account of the moment when Ailward realized that he could see, for embedded in the text here is an account of the care that had been applied to his now-empty eye-sockets. This, to my knowledge, has not 
been considered in studies of early medieval medicine and surgery, and deserves further attention. ${ }^{77}$

The third area in which hagiography is helpful is in providing material on the mutilation of female faces, saintly or otherwise. Disfigurement, it will be argued, is a highly-gendered concept, but where it has been discussed in previous studies, it has been seen as part and parcel of a series of mutilations inflicted chiefly on the male body, resulting in damage to the masculine identity. This is not surprising: the vast majority of cases documented in all types of source are of disfigured men. Chapter 5, however, will turn its attention to the minority of incidents concerning women. Hagiographic texts are valuable here because of their discourse on the dangers of female beauty. In Ruth Mazo Karras's words, "there was a strong strand in medieval thought that wanted women to internalize the blame for men's desires." ${ }^{78}$ Whilst this is a familiar trope to historians of medieval Europe, insufficient attention has been paid to the ways in which hagiography and legal sources locate the danger chiefly in the female face (as opposed to bodily form), and come to startlingly similar (and radical) conclusions as to solving this problem. Whilst laws threatened facial mutilation to destroy any further chance of adulterous women being considered attractive, female saints' lives embraced the practice enthusiastically as a model of the ultimate sacrifice in order to defend chastity and virginity. Beginning with early medieval examples of extreme mortification and mutilation in the face of barbarian threat, ${ }^{79}$ the theme was taken up again in hagiography of the twelfth and thirteenth centuries, precisely the period when judicial mutilation, too, was at its height and did not baulk at the idea of defacing a female felon.

\section{Medical Texts}

The early Middle Ages are commonly dismissed as the period where the medical knowledge of antiquity - in particular its theoretical groundings - was almost completely lost in Western Europe, and its surviving texts are often highlighted as at best empirical and at worst the product of ignorance and superstition. Even studies purporting to explore medieval medical practice focus their attention on a period when text-based knowledge was again circulating and being translated. ${ }^{80}$ In challenging this outlook, Peregrine Horden has demonstrated that the problem lies not only in a relative dearth of texts in comparison with the riches of the later Middle Ages, but also in an uneven field of study of those texts. 
Anglo-Saxon medicine, for example, is very well-explored in comparison with the outputs of continental scriptoria. ${ }^{81}$ Early Byzantine medicine, similarly, is well-documented and has been the subject of several studies. ${ }^{82}$ Yet there is another problem underlying the dismissal of the early Middle Ages, and that is the privileging of intellectual medicine over its practice. Medical knowledge was sometimes conceptualized as separate from medical practice, as the letters of the tenth-century polymath and teacher Gerbert of Aurillac (d. 1003) make clear. In one missive, to an unknown recipient looking for advice on a kidney stone, Gerbert responds: "Do not ask me to discuss what is the province of physicians, especially because I have always avoided the practice of medicine even though I have striven for a knowledge of it." ${ }^{83}$ In fact Gerbert's letters are suffused with medical analogies, as we shall see, and he did sometimes deign to offer advice, for all his protestation to the contrary. Yet he was an exceptional case: his book-collecting activities in fact give us a picture of the early medieval monastic world and its circulation and copying of texts. We can sometimes track the dissemination of knowledge, but medical texts will not show us the doctor at work.

How, then, can surviving medical texts assist in exploring responses to acquired disfigurement? We have already noted Bald's Leechbook as a valuable text for studying surgical procedures for congenital disfigurement such as hare lip. In terms of treating head injury, however, it is rather less detailed than some of the legal sources introduced above. And because surgery, as we shall see, was considered a subordinate, even separate, skill to medicine, dealing with surface injury rather than underlying symptoms and etiology, it may not show up even in specifically medical texts. As the study progresses, it will become apparent that early medieval medical interventions are noted not so much in medical texts, as in non-medical material where the practice of the doctor is often surprisingly well-documented.

\section{Archaeological Evidence}

This practice is also particularly visible in human cemetery remains. The science of osteoarchaeology is well-established, and has provided historians of medicine with rich details of the ravages of malnutrition, some diseases, gradual mechanical wear and tear, and acquired physical injury as these manifest themselves on the human skeleton. ${ }^{84}$ The head has attracted some attention in these studies, not least because there is a growing sample 
of early medieval cranial injuries that show clear signs of surgical intervention, including various forms of trepanation. This accords well with the evidence of legal sources describing procedures to reduce the pressure on the brain, carried out by the doctor (medicus) in the case of trauma to the skull. The implication of the archaeology is that early medieval surgery was considerably more sophisticated than has been thought hitherto: unlike the limbs, that arguably could be treated by anyone with a modicum of experience in the care of injured animals, the need for specialist care to the head may expose the early medieval surgeon at work. Archaeology can also, as we have already seen, reveal differentiation (or not) in the treatment of the impaired dead; more importantly for our purposes, archaeologists are increasingly able to determine whether an injury to the head or face was pre-, peri- or post-mortem. The first category is key here-some people might live for lengthy spells after sustaining a major wound that leaves evidence in the bones, and this prompts speculation as to what kinds of lives they might have led. ${ }^{85}$

\section{Iconography}

The evidence of iconography has already been alluded to in the depictions of rulers' facial hair and in consideration of Byzantine iconoclasm. But neither of these engages directly with the problem of disfigurement in medieval Europe. In fact, early medieval images (on parchment, panels or in stone sculptures) were largely unconcerned with the depiction of lived experience, still less with the depiction of those whose distorted or damaged features might have left them in a liminal position within their communities. (This is, of course, the central assumption to be tested within the present study.) In fact, we are dealing with a dearth not only of disfigured faces, but an almost complete absence of individual facial likenesses at all. ${ }^{86}$ Stephen Parkinson explains:

Medieval artists and patrons were... aware of the possibility of producing images whose appearance resembled that of their human models, but they chose not to do so. This was partly as a result of the belief that appearances were incapable of conveying a thing's essential nature, a widespread opinion in the early middle ages. ${ }^{87}$

This link between the visual image and the nature of the subject, he goes on, began to emerge only in the later Middle Ages, when much more naturalistic portraits begin to be made in paint and stone. Unsurprisingly, 
this coincided with Western Europe's rediscovery of physiognomy, offering ways to make a direct link between appearance and character traits.

In fact, whilst the physically impaired or the poverty-stricken might be portrayed in standardized representations of saints (physical impairment usually indicated by the presence of a wooden crutch or crawling-box), ${ }^{88}$ facial distortion or disfigurement is reserved, when it appears at all, for allegorical portrayals of sin or vice. ${ }^{89}$ (The female face appears, for example, in characterizations of vices such as luxuria.) That is, their value as evidence for actual disfigurement is negligible. Yet, just as the chroniclers and hagiographers drew upon biblical motifs to frame their narrative, so arguably the medieval judicial (and extrajudicial) practice of slicing off ears had its inspiration in accounts of the arrest of Christ, when the servant of the High Priest, Malchus, is physically attacked by Simon Peter, and this particular scene appears both in manuscripts such as the Winchester Psalter (c.1150) and in later medieval paintings such Duccio Boninsegna's Christ Taken Prisoner (1309-10), now in the Museo dell'Opera del Duomo in Siena. Malchus's face is already distorted and ugly in many depictions: his lost ear (which Christ, even then, restores to its place) cannot disfigure him any further.

Iconography has, however, been explored by Umberto Eco in his twin publications on beauty and ugliness. Utilizing works of art from antiquity to the modern day, he seems to have been able to complete his project on beauty far more satisfactorily than its counterpart on ugliness. Whilst "ugly" and "disfigured" are not precisely the same, the medieval texts that Eco consulted were not concerned to analyze ugliness itself, since for them it simply represented the inverse of beauty. As early as the seventh century, however, there is an important distinction made in Isidore of Seville's Etymologies between beauty as ornamentation and beauty as utility - a damaged body or face, therefore, might be interpreted in highly multi-valent ways. Thomas Aquinas would take up this problem in his Summa Theologiae in the thirteenth century, equating mutilation with ugliness and lack of use. ${ }^{90}$

Another reason to persist with visual images, even if they do not give us literal renditions of disfigured faces, is that sometimes they seem to serve as stand-ins for the power of the person they portray. A statue of the Frankish King Lothair (r. 954-86) was decapitated on the same day as Louis XVI lost his head in 1793. ${ }^{91}$ Icons of Byzantine emperors occupied a liminal space between straightforward portrait and saintly image; they were both, and neither. But their power was sufficient that faces might be 
removed and repainted during regime changes; the icon was a framework of power, only the occupant needed replacing. ${ }^{92}$ Imperial politics also lay at the heart of another iconographic source, coinage. Here, though, the idealization of the ruler seems to have trumped his or her actual physical appearance, and so the noseless Emperor Justinian II of Byzantium, for example, is shown without blemish. We shall return to his case as an example of how his disfigurement was treated in written sources.

\section{Approaches to Disfigurement}

Our sources, then, are numerous but recalcitrant. They are not directly concerned with the question of acquired disfigurement and its effects. Many of the examples discussed in the book will in fact center on the moment of disfigurement, the action of a just or unjust assailant, rather than its aftermath, and the present study cannot be considered a comprehensive survey of all cases of disfigurement in the early Middle Ages. Only a tiny minority of these reports can be read literally as a record of the incidence of facial disfigurement, but they can more profitably be mined for their assumptions about facial damage. For our purposes, one way of unlocking this evidence is to apply questions generated by modern studies of interpersonal and societal relations, testing the modern assumption that facial damage changed a person's life for the worse. Each of the following chapters, therefore, takes a concept generated by modern sociological, anthropological and gender-inflected research as a starting point in its exploration of medieval texts about the damaged face.

Chapter 2, The Face, Honor and "Face," asks the question "What is a face, and how does it function in social relations?" This may be a somewhat disingenuous entry point, yet it is an important one to pose since several recent medieval studies play on the multiple meanings of the word "face" to imply not only the physical features of a person, but that deeper sense of personhood we met in Groebner's discussion above. Giorgio Agamben and François Delaporte have both interrogated the face as a surface, connected (or not) to the person behind or beneath. ${ }^{93}$ Stephen Pattison, too, has reflected upon the relationship between the physical and metaphorical face. ${ }^{94}$ To "lose face" is a well-used phrase, but whilst it may function in the modern western world as shorthand for a humiliation of sorts, or loss of dignity, in many cultures it has a far greater specificity of meaning, and conceptually is the very glue binding together and regulating social relations. ${ }^{95}$ This demands a certain care in the use of the term-which has not 
been apparent within historical studies - when utilizing it to convey loss of status in medieval culture. Even then, the metaphorical loss of face might or might not involve loss of or damage to physical facial features (hence Groebner's play on the term in Defaced and in his associated article): the potential for confusion is therefore apparent. ${ }^{96}$ Associated with the idea of face, but not exactly coterminous with it, is that of honor. Whilst we shall discuss the meanings of honor in detail below, it is important to flag up here the strong association visible in the early medieval sources between the physical face and personal honor, although couched in different terms for men and women. Whilst it might be assumed that damage to women's faces would have been more devastating to their chances of social acceptance, in fact most of the source material indicates that it was men who had more to lose from disfigurement. The reasons for this will be explored later.

Chapter 3 further investigates the troubled connection between many cases of disfigurement and claims to authority expressed in medieval legal sources. Framing this discussion will be a consideration of Giorgio Agamben's work on sovereign power ${ }^{97}$ : whilst early medieval law codes universally condemned interpersonal violence and poured particular opprobrium on damage inflicted to the head and face, medieval rulers reserved the right to inflict exactly the same kinds of damage as punishment for transgressions against the law, particularly in cases of repeated theft, adultery or treason. When such punishments became frequent or unjustified, however-when, in Agamben's formulation, the exceptional became the norm-medieval writers report them as atrocities, making clear to readers that such behaviors were unacceptable, despite the ruler's special status as constituting, rather than being bound by, the law.

The flipside to honor, in most medieval discussions, was shame. This introduces the theoretical framework explored in Chapter 4, the idea of disfigurement as stigma. Elaborated in detail by Erving Goffman in the 1960s, and influential on generations of sociologists and historians since, stigma is a powerful analytical concept with which to explore medieval disfigurement. As Goffman points out, a stigmatizing condition could be visible or invisible, the product of a person's own actions or inflicted upon her or him by the wider social group. Different categories of stigma have been elaborated by subsequent studies, and their negative inflections explored in detail. But what is particularly interesting about stigma for a medievalist is the fact that the marks of shame, stigmata, had an entirely different valence in later medieval Christian society, as the privileged marks 
of God's favor toward an earthly recipient. The chapter will therefore investigate the biblical ambivalence toward marking of any kind.

The fifth chapter will take a gendered approach to disfigurement in terms of its disempowering function, but will then examine in detail the minority of documented cases of disfigured women. How do these reports differ from those dealing with men? Was a woman's face only equated with beauty and marriageability, and/or an asset put at risk by transgressive behavior? Given the strong tradition within hagiography of the earlier and later Middle Ages of women disfiguring themselves when under threat of sexual assault or unwanted marriage, to what extent were these ideas typical of the contexts within which such texts were produced? In what circumstances were men's and women's faces treated similarly, and what were the major differences? This chapter will explore issues such as visibility and modesty among women: even with a disfigured face, was it possible for a woman to "pass" more easily because she would in any case be required to partly conceal her head with wraps or a hood? Throughout the chapter, "gender" will be understood as a web of power relations between not only men and women, but within each group. I have suggested elsewhere that the power to disfigure a woman signaled not so much a man's authority over her, but his position vis-à-vis other men, for whom control over their households and family was central to their own masculinity. ${ }^{98}$ This will be developed further as the chapter progresses.

The question of how visible a disfigurement might be brings us to the vexed question of the medieval and modern gaze, examined in Chapter 6. "Ways of seeing" as an approach, pioneered by John Berger in the 1970s, has been largely confined to the field of art history since then, though here it offers an entry point into visual representation and consumption. More germane to the present study is Rosemarie Garland-Thomson's groundbreaking work on staring. ${ }^{99}$ We have already touched upon the fact that medieval artwork of this early period did not seek to depict the fleshly figure realistically, but how do the sources portray the act of looking at other people? This chapter seeks to find out whether the "flicker of revulsion" can be detected in descriptions of the disfigured. Modern neuropsychological studies about face perception assist here in setting out the evolutionary parameters of the human gaze. Face perception is-and according to the studies always has been-a key element in social interaction, the first point of contact between humans. Medieval texts abound with descriptions of faces, and the later rediscovery of the pseudo-science of physiognomy concentrated attention on the facial features like never 
before. A key question in this chapter will be how a disfigured face might fit into or disrupt existing schemata for facial description: did political considerations, for example, trump historical accuracy when it came to depictions or descriptions of the disfigured elite?

The theoretical chapters will enable the study to examine the ways in which disfigurement was presented by the medieval sources, and suggest some reasons why the representation took certain forms. Chapter 7 distills remaining examples of actual disfigurement or disfiguring head injury, and examines the evidence from texts and archaeology that suggest ways in which disfigured individuals and/or their carers might seek solutions to their damaged appearance, whether through concealment or actual treatment. Included here will be the rare cases documenting a "rehabilitation" of sorts, whether medical or moral. Just as there was a spectrum of disfigurement in our sources, so the level of perceived need for help might vary considerably. We have already briefly considered clothing around the head and face; to this might be added cosmetics, self-isolation (the likely route of the stigmatized individual, according to Goffman) and medical or surgical treatments to repair wounds and/or restore the skin blemished by injury or burns. The evidence for all of these is scant, and likely only to be encountered in tangential references, but striking medical metaphors on wound care in the pastoral letters of clergy suggest that knowledge was not actually lost, simply transferred into a different conceptual arena. We return full circle to the problem we set out with, the ideological framework within which early medieval writing was produced and consumed: exploring the face as a focus may shed significant new light on the processes of its production.

\section{Notes}

1. Muscular dystrophy sufferer Denis Creegan, "Adapt or succumb," in Stigma: the Experience of Disability, ed. Paul Hunt (London: Geoffrey Chapman, 1966), 114. [The nature of each author's disability preceded his or her essays.]

2. Consider the case of Bibi Aisha, discussed in Patricia Skinner, "The gendered nose and its lack: 'medieval' nose-cutting and its modern manifestations," Journal of Women's History, 26.1 (2014): 45-67, whose nose was cut off by her husband's relatives and whose reconstructive surgery, courtesy of an American philanthropic foundation, was delayed by the need to give her counseling. See also the 
cases featured in Channel 5 TV series Making Faces, aired in October 2012, following the maxillofacial unit at Birmingham's Queen Elizabeth Hospital in the UK: http://www.channel5. com/shows/making-faces [accessed 29 July 2015].

3. Kumaran Shanmugarajah, Safina Gaind, Alex Clarke and Peter E. M. Butler, "The role of disgust emotions in the observer response to facial disfigurement," Body Image, 9 (2012): 455-461.

4. William Ian Miller, The Anatomy of Disgust (Cambridge, MA: Harvard University Press, 1997), 27.

5. For example Katie Piper (attacked with acid), Beautiful (London: Ebury Press, 2011); Tina Nash (whose partner gouged out her eyes), Out of the Darkness (London: Simon and Schuster, 2012); James Partridge (burns), Changing Faces: the Challenge of Facial Disfigurement (London: Penguin, 1990). This is just a sample from the UK alone. Veterans: Suzannah Biernoff, "The rhetoric of disfigurement in First World War Britain," Social History of Medicine, 24.3 (2011): 666-685; Edward Bishop, McIndoe's Army: the Story of the Guinea Pig Club and its Indomitable Members (London: Grub Street, 2004); Falklands War veteran Simon Weston, Going Back: Return to the Falklands (London: Penguin, 1992).

6. E.g. the 1914FACES2014 Exeter Project: http://blogs.exeter. ac.uk/1914faces2014/ [accessed 13 February 2014]. Biernoff, "The rhetoric of disfigurement," 668.

7. Sander Gilman, Making the Body Beautiful: a Cultural History of Aesthetic Surgery (Princeton/Oxford: Princeton University Press, 1999); D. Reisberg and S. Habakuk, "A history of facial and ocular prosthetics," Advances in Ophthalmic Plastic Reconstructive Surgery, 8 (1990): 11-24.

8. Quoted at length in Biernoff, "Rhetoric," 671. Biernoff comments that the directness of Muir's prose would probably be replaced nowadays with a "more sensitive (and more euphemistic) treatment of disfigurement."

9. Erving Goffman, Stigma: Notes on the Management of Spoiled Identity (Englewood Cliffs, NJ: Prentice-Hall/London: Penguin, 1963); Henri Tajfel, "Intergroup relations, social myths and social justice in social psychology," in The Social Dimension, ed. H. Tajfel, II (Cambridge: Cambridge University Press, 1984), 695-716. Durkheim's theory of anomie, a breakdown of social norms 
resulting in deviant behavior, was expounded in his De la division du travail social [The Division of Labour in Society] (Paris: Presses universitaires de France, 1893).

10. Even recently, archaeologists E. and G. Craig have commented that "facial disfigurement had the strong potential to result in disability in the early medieval period": "The diagnosis and context of a facial deformity from an Anglo-Saxon cemetery at Spofforth, North Yorkshire," International Journal of Osteoarchaeology, 23 (2013): 631-9, at 636.

11. The trauma is vividly captured in a series of portrait paintings by Mark Gilbert, of patients before, during and after surgeries, commissioned by surgeon Iain Hutchinson for the Saving Faces charity, most recently exhibited in Saving Faces at the University of Exeter, 25 February to 25 March 2015. See also Rosemarie GarlandThomson, Staring: How We Look (Oxford: Oxford University Press, 2009), 6-7, featuring Gilbert's portrait of the late Henry de Lotbiniere.

12. Michael McVaugh, The Rational Surgery of the Middle Ages (Firenze: SISMEL-Edizioni del Galluzzo, 2006).

13. See Emily Cock, “'Lead[ing] 'em by the nose into public shame and derision': Gaspare Tagliacozzi, Alexander Read and the lost history of plastic surgery, 1600-1800," Social History of Medicine, 28.1 (2015): 1-21, with references to earlier literature; the conference Modified Bodies and Prosthesis in Medieval and Early Modern England, held at the University of Sussex in May 2014 (publication in preparation). See also Naomi Baker, Plain Ugly: the Unattractive Body in Early Modern Culture (Manchester: Manchester University Press, 2010).

14. Peregrine Horden, "What's wrong with early medieval medicine?" Social History of Medicine, 24.1 (2011): 5-25, succinctly dissects the reasons for the neglect of the earlier period. See also the special issue of Social History of Medicine, 13.2, co-edited by Horden and Emilie Savage-Smith, dealing with The Year 1000: Medical Practice at the End of the First Millennium. A welcome exception to the rule is the work of Clare Pilsworth, Healthcare in Early Medieval Northern Italy: More to Life than Leeches (Turnhout: Brepols, 2014), which takes a holistic view and rejects the distinction between "learned" and "practical" medicine. 
15. E.g. The Final Argument: the Imprint of Violence on Society in Medieval and Early Modern Europe, ed. Donald J. Kagay and L. J. Andrew Villalon (Woodbridge: Boydell, 1998); John Gillingham, "Killing and mutilating political enemies in the British Isles from the late twelfth to the early fourteenth century: a comparative study," in Britain and Ireland 900-1300: Insular Responses to Medieval European Change, ed. B. Smith (Cambridge: Cambridge University Press, 1999), 114-134; D. Baraz, Medieval Cruelty: Changing Perceptions from Late Antiquity to the Early Modern Period (Ithaca, NY: Cornell University Press, 2003); P. Freedman, "Atrocities and the execution of peasant rebel leaders in later medieval and early modern Europe," Medievalia et Humanistica, n.s. 31 (2005): 101-113; Violences souveraines au Moyen Age, ed. F. Feronda et al. (Paris: PUF, 2010); Daniel Lord Smail, "Violence and predation in later medieval Mediterranean Europe," Comparative Studies in Society and History, 54.1 (2012): 7-34. Rather more sophisticated readings of violence in texts are offered by Albrecht Classen, Violence in Medieval Courtly Literature: a casebook (New York: Garland, 2004), and the contributors to Violence and the Writing of History in the Medieval Francophone World, ed. Noah D. Guynn and Zrinka Stahuljak (Cambridge: D. S. Brewer, 2013) and History-Writing and Violence in the Medieval Mediterranean, ed. Antonella Liuzzo Scorpo and Jamie Wood, special issue of Al-Masāq: Journal of the Medieval Mediterranean, 27 (2015).

16. On judicial procedures see Mitchell Merback, The Thief, the Cross and the Wheel: pain and the spectacle of punishment in medieval and renaissance Europe (London: Reaktion Books, 1999); Klaus van Eickels, "Gendered violence: castration and blinding as punishment for treason in Normandy and Anglo-Norman England," Gender and History, 16.3 (2004): 588-602.

17. Piers Mitchell, Medicine in the Crusades: Warfare, Wounds and the Medieval Surgeon (Cambridge: Cambridge University Press, 2004). And see below, Chap. 7.

18. Framing Medieval Bodies, ed. Sarah Kay and Miri Rubin (Manchester: Manchester University Press, 1994). The diversity of the field even a decade or so in was examined critically by Caroline Bynum, "Why all the fuss about the body? A medievalist's 
perspective," Critical Inquiry, 22 (1995): 1-33, at 5: "despite the enthusiasm for the topic, discussions of the body are almost completely incommensurate - and often mutually incomprehensible across the disciplines." Recent studies include Fleshly Things and Spiritual Matters: Studies on the Medieval Body in Honor of Margaret Bridges, ed. Nicole Nyffenegger and Katrin Rupp (Newcastle: Cambridge Scholars Press, 2011) and Disembodied Heads in Medieval and Early Modern Culture, ed. C. G. Santing, B. Baert and A. Traninger (Leiden: Brill, 2013).

19. Miri Rubin, "The person in the form: medieval challenges to bodily 'order'," in Framing Medieval Bodies, 100-122, at 101.

20. Martin Porter, "A persistent fisnomical consciousness, c.400BCc.1470CE," in id., Windows of the Soul: The Art of Physiognomy in European Culture, 1470-1780 (Oxford: Oxford University Press, 2005); Seeing the Face, Seeing the Soul: Polemon's Physiognomy from Classical Antiquity to Medieval Islam, ed. Simon Swain (Oxford: Oxford University Press, 2007).

21. Irina Metzler's two wide-ranging surveys, Disability in Medieval Europe: Thinking about Physical Impairment during the High Middle Ages, 1100-1400 (London and New York: Routledge, 2006) and $A$ Social History of Disability in the Middle Ages: Cultural Considerations of Physical Impairment (London and New York: Routledge, 2013) laid out the groundwork with an impressive array of examples; Edward Wheatley, Stumbling Blocks before the Blind: Medieval Constructions of a Disability (Ann Arbor: University of Michigan Press, 2010), challenges the monolithic approach to specific impairment by illustrating how fluid the category of "blindness" could be. The deaf are rather less represented, only featuring in S. de Vriendt, "Doven in de middeleeuwen: drie vragen aan mediëvisten," in Een School spierinkjes: Kleine opstellen over Middelnederlandse artes-literatuur, ed. W. P. Gerritsen, Annelies van Gijsen and Orlanda S. H. Lee (Middeleeuwse studies en bronnen, 26, Hilversum: Verloren, 1991), 168-171, and several studies on the deaf Theresa de Cartagena. See also Kristina L. Richardson, Difference and Disability in the Medieval Islamic World: Blighted Bodies (Edinburgh: Edinburgh University Press, 2012); Disability in the Middle Ages: Reconsiderations and Reverberations, ed. Joshua Eyler (Aldershot: Ashgate, 2010); and The Treatment of Disabled Persons in Medieval Europe, ed. Wendy Turner and Tory Vandeventer Pearman (Lampeter: Edwin Mellen, 2010). 
22. Norbert Elias, The Civilizing Process, vol 1: The History of Manners, trans E. Jephson (Oxford: Blackwell, 1969, original German edition 1939). Although thought of as a recent phenomenon, perhaps influenced by the translation of Elias' work into English, the current wave of studies was preceded over a century ago by Henry Osborn Taylor, The Medieval Mind: A History of the Development of Thought and Emotion in the Middle Ages, 2 vols (London: Macmillan, 1911; repr. Cambridge, MA: Harvard University Press, 1959 and 1962). The topic has been promoted strongly by Barbara H. Rosenwein: see Anger's Past: The Social Uses of an Emotion in the Middle Ages, ed. Barbara H. Rosenwein (Ithaca, NY: Cornell University Press, 1998); Barbara H. Rosenwein, "Writing without fear about early medieval emotions," and Carolyne Larrington, "The psychology of emotion and the study of the medieval period," Early Medieval Europe, 10 (2001): 229-234 and 251-6 respectively; Barbara H. Rosenwein, "Worrying about emotions in history," American Historical Review, 107 (2002): 821-845; ead., "Identity and emotions in the early middle ages," in Die Suche nach den Ursprüngen: Von der Bedeutung des frühen Mittelalters, ed. Walter Pohl (Vienna: VÖAW, 2004), 129-137; ead., "Histoire de l'émotion: méthodes et approches," Cabiers de civilisation médiévale, 49.193 (2006): 33-48, and ead., Emotional Communities in the Early Middle Ages (Ithaca, NY: Cornell University Press, 2006). The last decade has seen a flurry of research across Europe: Codierungen von Emotionen im Mittelalter/Emotions and Sensibilities in the Middle Ages, ed. Stephen C. Jaeger and Ingrid Kasten (Berlin: De Gruyter, 2003); Histoire de la Vergogne [History of Shame], a special issue of Rives Méditerranéennes, 31 (2008); Le sujet des émotions au Moyen Âge, ed. Damian Boquet and Piroska Nagy (Paris: Editions Beauchesne, 2009); Politiques des émotions au Moyen $\hat{A} g e$, ed. Damian Boquet and Piroska Nagy (Florence: SISMELEdizioni del Galluzzo, 2010). The establishment of the Australian Research Council Centre of Excellence for the History of the Emotions (Europe 1100-1800) at the University of Western Australia in 2011 has provided an institutional base for much research since then.

23. Horden, "What's wrong," who highlights the contrast between the well-developed study of Anglo-Saxon texts in comparison with 
continental Latin manuscripts; Clare Pilsworth, "'Can you just sign this for me John?': Doctors, charters and occupational identity in early medieval northern and central Italy," Early Medieval Europe, 17 (2009): 363-388; Patricia Skinner, Health and Medicine in Early Medieval Southern Italy (Leiden: Brill, 1997). And see above, note 14 . The potential of legal texts for the history of medicine is illustrated by the essays in Medicine and the Law in the Middle Ages, ed. Wendy Turner and Sara Butler (Leiden: Brill, 2014), although the bulk of the material discussed here is later medieval.

24. See below, note 85 .

25. Paul Edward Dutton, Charlemagne's Mustache and other Cultural Clusters of a Dark Age (New York: Palgrave Macmillan, 2004), especially the eponymous first essay, 3-42 and notes, 201-9; Robert Bartlett, "Symbolic meanings of hair in the middle ages," Transactions of the Royal Historical Society, 6th series, 4 (1994): 43-60; Miller, Anatomy of Disgust, 54-58, discusses the horror of excessive hair or hair out of place. As we shall see in Chap. 2, facial hair matters.

26. The term of course comes from R. I. Moore, The Formation of a Persecuting Society (Oxford: Blackwell, 1987, 2nd ed., 2007). As manifestations of these harsher attitudes we might cite studies that examine how civic authorities dealt with the disabled and begging poor, demanding evidence of their disability: Sharon Farmer, Surviving Poverty in Medieval Paris (Ithaca, NY: Cornell University Press, 2002); Metzler, Social History, Chap. 4. On the intersection of poverty and disability, see also Ephraim Shoham-Steiner, "Poverty and disability: a medieval Jewish perspective," in The Sign Languages of Poverty, ed. Gerhard Jaritz (Vienna: VÖAW, 2007), 75-94, developed in id., On the Margins of a Minority: Leprosy, Madness and Disability among the Jews of Medieval Europe (Detroit: Wayne State University Press, 2014).

27. The Dark Side of Childhood in Late Antiquity and the Middle Ages, ed. Katariina Mustakallio and Christian Laes (Oxford: Oxbow, 2011); Mayke de Jong, In Samuel's Image: Childhood Oblation in the Early Medieval West (Leiden: Brill, 1996); Dudley Wilson, Signs and Portents: Monstrous Birth from the Middle Ages to the Enlightenment (London and New York: Routledge, 1993); John Boswell, The Kindness of Strangers: the Abandonment of Children 
in Western Europe from Late Antiquity to the Renaissance (Chicago: Chicago University Press, 1988).

28. L'Enfant et la vie familiale sous l'Ancien Régime (Paris: Plon, 1960). Translated into English by Robert Baldick as Centuries of Childhood: A Social History of Family Life (New York: Vintage, 1962); the Annales de Démographie historique for 1973 was a special issue on Enfance et sociétés, responding to Ariès. More recent challenges are Barbara Hanawalt, Growing up in Medieval London: The Experience of Childhood in History (New York and Oxford: Oxford University Press, 1995) and Nicholas Orme, Medieval Children (New Haven, CT: Yale University Press, 2003).

29. Sally Crawford, Childhood in Anglo-Saxon England (Stroud: Sutton, 1999), 95.

30. Craig and Craig, "Diagnosis and context of a facial deformity."

31. Edward Wheatley, pers. comm., is currently preparing a study on this subject.

32. Most notably castration, with which disfigurement has an entangled history: see Castration and Culture in the Middle Ages, ed. Larissa Tracy (Cambridge: D. S. Brewer, 2013).

33. Targeting children and infants, as we shall see later in this chapter, was used as a way to mark the perpetrator as evil beyond redemption.

34. Cf. the comments in Biernoff, "Rhetoric of disfigurement."

35. Valentin Groebner, Defaced: the Visual Culture of Violence in the Later Middle Ages (New York: Zone, 2004), 76.

36. A useful survey of the disease's effects in the past, identified by archaeological evidence, is Keith Manchester, "Medieval leprosy: the disease and its management," in Medicine in Early Medieval England: Four Papers, ed. Marilyn Deegan and D. G. Scragg (Manchester: Centre for Anglo-Saxon Studies, 1987), 27-32.

37. Acta Sanctorum, vol. XI, 20 April, Vita Ven. Oda Praemonstratensis c.V.20, p. 776. See Patricia Skinner, "Marking the face, curing the soul? Reading the disfigurement of women in the later middle ages," in Medicine, Religion and Gender in Medieval Culture, ed. Naoë Kukita Yoshikawa (Woodbridge: Boydell, 2015), 287-318, for a fuller discussion of Oda. Timothy S. Miller and John W. Nesbitt, Walking Corpses: Leprosy in Byzantium and the Medieval West (Ithaca, NY: Cornell University Press, 2014), 6-9, discuss definitions of the disease. 
38. Elma Brenner, "Recent perspectives on leprosy in medieval western Europe," History Compass, 8.5 (2010): 388-406; ead., Leprosy and Charity in Medieval Rouen (Woodbridge: Boydell, 2015); Luke Demaitre, Leprosy in Premodern Medicine (Baltimore: Johns Hopkins University Press, 2007); Carole Rawcliffe, Leprosy in Medieval England (Woodbridge: Boydell, 2006); Guenter P. Risse, Mending Bodies, Saving Souls: a History of Hospitals (Oxford: Oxford University Press, 1999), Chap. 4 on leper hospitals and seclusion; Peter Richards, The Medieval Leper and his Northern Heirs (Cambridge: Brewer, 1977). A recent, major archaeological find relating to the disease is reported by Simon Roffey and Katie Tucker, "A contextual study of the medieval hospital and cemetery of St Mary Magdalen, Winchester, England," International Journal of Paleopathology, 2.4 (2012): 170-180.

39. Skinner, "Marking the face," highlights the case of Margaret of Cortona.

40. This incomplete statistical exercise is intended simply to illustrate the fluidity of terminology when searching for disfigured people, and does not reflect the range of examples ultimately found (for which see below, Appendix I).

41. Leges Langobardorum, ed. F. Bluhme, Rothari c. 341, in MGH LL, IV, ed. G. H. Pertz (Hannover: Hahn, 1868); Matthew: MGH SS, XXVIII, Ex Rerum Anglicarum Scriptoribus saec. XIII, ed. F. Liebermann and R. Pauli (Hannover: Hahn, 1888), 119.

42. E. H. Freshfield, A Manual of Later Roman Law: the Ecloga ad Procheiron Mutata (Cambridge: Cambridge University Press, 1927), 138; O ПР'OXEIPO N NOMOC: Imperatorum Basilii, Constantini et Leonis Prochiron, ed. C. E. Zachariae v. Lingenthal (Heidelberg: Mohr, 1837), 153. I have been unable to identify the root verb for $\alpha \pi \sigma \sigma \varphi \alpha \lambda \tau \iota \omega \sigma \alpha \varsigma$ - is it related to $\alpha \pi \sigma \psi \bar{\imath} \lambda \hat{o} \omega$, meaning to strip of hair or make bald (and implying therefore that it is the beard, not the person, who is "destroyed")?

43. Leechdoms, Wortcunning and Starcraft of Early England, ed. O. Cockayne, 3 vols (London: Longmans and Green, 1864-6), II, 53, 77-81 (blotches), 59 (hare lip). And see below, Chap. 7.

44. See the essays in Why the Middle Ages Matter, ed. Celia Chazelle et al. (New York: Routledge, 2012); and from a feminist and economic perpective Judith Bennett, "Less money than a man would take," in her History Matters: Patriarchy and the Challenge of 
Feminism (Philadelphia: University of Pennsylvania Press, 2006), 82-107; and Skinner, "Gendered nose."

45. Miller, Anatomy of Disgust, 11; id., Humiliation and Other Essays on Honor, Social Discomfort and Violence (Ithaca/London: Cornell University Press, 1998), 197.

46. Richard Horton, "Offline: the moribund body of medical history," The Lancet, vol 384, issue 9940 (2014), 292. Carsten Timmermann, "Not moribund at all! An historian of medicine's response to Richard Horton," The Guardian, 4 August, 2014, online at http://www.theguardian.com/science/the-h-word/2014/ aug/04/not-moribund-historian-medicine-response-richard-horton [accessed 14 August 2014], unfortunately missed the opportunity to include the premodern in his rebuttal of Horton's case. For this see Pratik Chakrabarti, Graham Mooney and Patricia Skinner, "Editorial," Social History of Medicine, 27 (2014): 629-631.

47. Chris Mounsey, "Variability: beyond sameness and difference," in The Idea of Disability in the 18th Century, ed. Chris Mounsey (Plymouth: Bucknell University Press, 2014), 1-30.

48. I have explored this issue from the point of view of the early medieval warrior in Patricia Skinner, "Visible prowess? Reading men's head and face wounds in early medieval European sources to 1000CE," in Wounds and Wound Repair in Medieval Culture, ed. Kelly de Vries and Larissa Tracy (Leiden: Brill, 2015) 81-101.

49. See below, Chap. 4, for examples.

50. Patrick Wormald, The Making of English Law: from Alfred to the Twelfth Century, vol 1 (Oxford: Blackwell, 1999), 44: “it was by memorizing them that crystallising gentes fixed the identity of their particular law."

51. Ibid., 46 and 124 (quote). Wormald explicitly updated his earlier essays on the subject in this book and in his collection of essays, Legal Culture in the Early Medieval West: Law as Text, Image and Experience (London: Hambledon, 1999).

52. Although the intensity of legislation varied widely between individual emperors, as is made clear by the contributions to Law and Society in Byzantium: Ninth-Twelfth Centuries, ed. A. Laiou and D. Simon (Washington: Dumbarton Oaks, 1994).

53. G. Koziol, "Leadership: why we have mirrors for princes but none for presidents," in Why the Middle Ages Matter, 183-198. 
54. E.g. Charles Insley, "Rhetoric and ritual in late Anglo-Saxon charters," in Medieval Legal Process: Physical, Spoken and Written Performance in the Middle Ages, ed. Marco Mostert and Paul Barnwell (Turnhout: Brepols, 2011), 109-121. Wormald's work is reviewed and built upon in Early Medieval Studies in Memory of Patrick Wormald, ed. Stephen Baxter, Catherine Karkov, Janet Nelson and David Pelteret (Aldershot: Ashgate, 2009).

55. See below, Appendix 2, for a list.

56. Most notably the work of the late Lisi Oliver: "Sick maintenance in Anglo-Saxon law," Journal of English and German Philology, 107.3 (2008): 303-326; ead., "Protecting the body in early medieval law," in Peace and Protection in the Middle Ages, ed. T. B. Lambert and D. Rollason (Durham: Centre for Medieval and Renaissance Studies, 2009), 60-77; and ead., The Body Legal in Barbarian Law (Toronto: Toronto University Press, 2011).

57. Specifically, Alemannic laws from the seventh and eighth centuries in Leges Alamannorum, Pactus I.4 and Leges A, LVII.4 and B, LIX.4, ed. K. A. Eckhardt, MGH LL nat. Germ., V.1 (Hannover: Hahn, 1966); Rothari's edict for the Lombards, dated 643, c. 47, in Leges Langobardorum, ed. F. Bluhme, MGH LL, IV, ed. G. H. Pertz (Hannover: Hahn, 1868); Lex Frisionum, XXII.71, ed. K. de Richthofen, in MGH LL, III, ed. G. Pertz (Hannover: Hahn, 1863). Compare the compilation of Welsh laws attributed to the tenth-century King Hywel Dda, where the bone makes a sound when falling into a copper basin: The Laws of Hywel Dda The Book of Blegywryd, tr. M. Richards (Liverpool: Liverpool University Press, 1964), 64. Clearly size mattered in all these cases. According to Rolf H. Bremmer, Jr, "'The children he never had, the husband she never served': castration and genital mutilation in medieval Frisian law," in Castration and Culture, 108-130, the extraordinarily detailed provisions of Frisian law are unlikely ever to have been put into effect.

58. E.g. when the citizens of Rome ejected their newly-elected pope John XIII in 965, according to Benedict of Soracte, "some hit his head and others gave him slaps in the face [alii percutiebant caput eius, alii alapas in facies eius percutiebat [sic]": Benedicti S. Andreae Monachi Chronicon, in MGH SS, III, ed. G. H. Pertz (Hannover: Hahn, 1839), 719.

59. Below, Chap. 4 , note 8 . 
60. ...fecit, quod infelix illa gens Friolana, mares et femine, magni et parvi, clerici et laici, generaliter omnes cesi et deformati, per Lonbardiam et marchiam signum deferunt Ecelinice rabiei. Nichil quoque profuit parvulis innocentibus non peccasse, immo, cum triplicem penam senes et iuvenes paterentur, oculis naribus et pedibus mutilati, infantes et innocentes penam quadruplicem habuerunt, nam Ececlini iussu naribus et pedibus deformati, cecati sunt oculis et parvis genitalibus sunt exsecti. Fuit autem hec Ecelini ultima perpetrata crudelitas in predicto anno Domini [1259], mense Iunii circa finem: Rolandini Patavini Chronica XI.17, ed. P. Jaffé, in MGH SS XIX: Annales Aevi Suevici, ed. G. H. Pertz (Hannover: Hahn, 1866), 136.

61. MGH Epp Saeculi XIII e Regestis Pontificum Romanorum Selectae, ed. C. Rodenberg, III, letter 481 (Berlin: Weidmann, 1894), 445-6.

62. Similarly, Frederick II's treatment of (presumably mercenary) Genoese archers, "manu et oculo mutilati" after his capture of Milan in 1245 is written up as an act of cruelty: Bartholomaei Scribae Annales, s.a. 1245, in MGH SS, XVIII, ed. G. H. Pertz (Hannover: Hahn, 1863), 219.

63. It appears to have gained particular popularity as a motif in texts and iconography of the twelfth century: Einat Segal, "Sculpted images from the eastern gallery of the St-Trophime cloister in Arles and the Cathar heresy," in Difference and Identity in Francia and Medieval France, ed. Meredith Cohen and Justine Firnhaber-Baker (Farnham and Burlington: Ashgate, 2010), 67-69, highlights the motif in chronicle evidence from the century; other creative uses are discussed by John Marlin, "The Investiture Contest and the rise of Herod plays in the twelfth century," Early Drama, Art and Music Review, 23 (2000): 1-18, and Miriam Anne Skey, "The iconography of Herod in the Fleury Playbook and in the visual arts," in The Fleury Playbook: Essays and Studies, ed. C. Clifford Flanigan, Thomas P. Campbell and Clifford Davidson (Kalamazoo: Medieval Institute, 1985), 120-143.

64. Gregorii Episcopi Turoniensis Libri Historiarum X, ed. B. Krusch and W. Levison, MGH SS Rer Merov., I (Hannover: Hahn, 1951) [hereafter GT], Bk VI, 46.

65. Guy Halsall, Warfare and Society in the Barbarian West, 450-900 (London: Routledge, 2003), 1-2. 
66. Antonella Liuzzo Scorpo and Jamie Wood, "Introduction: historywriting and violence in the medieval Mediterranean," Al-Masāq, 27 (2015): 1-6, at 5.

67. Thietmar Mersebergensis Episcopi Chronica, ed. Robert Holtzmann, MGH SSRG n.s. IX (Berlin: Weidmann, 1935) [hereafter Thietmar], V.30.

68. On the ambiguity of the passage in question, and its subsequent history, see Ruth Mellinkoff, The Mark of Cain: An Art Quantum (Berkeley: University of California Press, 1981).

69. Anna: see below, Chap. 6; Amatus: see below, Chap. 4, note 84; Gregory: above, note 64 .

70. I explore Norman historiography on this theme in Patricia Skinner, "The Political uses of the body in Norman texts," paper read at People, Texts and Artefacts: Cultural Transmission in the Norman Worlds of the Eleventh and Twelfth Centuries, Ariano Irpino, Italy, 20-22 September 2013. A publication of this conference, and its follow-up at Cambridge in 2014, is planned.

71. E.g. Valerie J. Flint, "The early medieval medicus, the saint and the enchanter," Social History of Medicine 2.2 (1989): 127-145; Darryl Amundsen, Medicine, Society and Faith in the Ancient and Medieval Worlds (Baltimore: Johns Hopkins University Press, 1996); Patricia Skinner, "A cure for a sinner: sickness and healthcare in medieval southern Italy," in The Community, the Family and the Saint: Patterns of Power in Early Medieval Europe, ed. J. Hill and M. Swann (Leeds/Turnhout, Brepols, 1998), 297-309; Clare Pilsworth, "Medicine and hagiography in Italy, 800-1000," Social History of Medicine, 13.2 (2000): 253-264.

72. Metzler, Disability in Medieval Europe, has an appendix of cases from three sample hagiographic texts.

73. The Book of St Foy, tr. Pamela Sheingorn (Philadelphia: University of Pennsylvania Press, 1995), 50.

74. See the essays collected in Icon and Word: the Power of Images in Byzantium, ed. Anthony Eastmond and Liz James (Aldershot: Ashgate, 2003). On iconoclasm, Leslie Brubaker and John Haldon, Byzantium in the Iconoclast Era c.680-850: a History (Cambridge: Cambridge University Press, 2011), noting at 199 their warning that much of the hagiography of persecution ("the myth or legend of opposition [to iconoclasm]") was constructed after the final 
restoration of icons in the ninth century. For examples of punishments, see below, Chap. 3 .

75. The Wulfstan episode is quoted at length and extensively discussed by Wheatley, Stumbling Blocks, 175-179 and considered by van Eickels, "Gendered violence," 595. Becket: The Miracula of Benedict of Peterborough, reproduced in English Lawsuits from William I to Richard I, volume II: Henry II and Richard I, ed. R. C. Van Caenegem (London: Selden Society vol 107, 1991), case 471B, 509-514. And see below, Chap. 7.

76. See, e.g. Larissa Tracy, "'Al defouleden is holie bodi': castration, the sexualization of torture and anxieties of identity in the South English Legendary," in Castration and Culture, 94-6.

77. The passage will be discussed below in Chap. 7 .

78. Ruth Mazo Karras, Sexuality in Medieval Europe: Doing unto Others (New York: Routledge, 2005), 39.

79. On the earlier cases, Jane Tibbetts Schulenberg, Forgetful of their Sex: Female Sanctity and Society c.500-1100 (Chicago: Chicago University Press, 1998), 145-8 (Eusebia of Marseilles, Ebba of Coldingham and Oda of Brabant). On later cases Claire Marshall, "The politics of self-mutilation: forms of female devotion in the late middle ages," in The Body in Late Medieval and Early Modern Culture, ed. Darryl Grantley and Nina Taunton (Aldershot: Ashgate, 2000), 11-22, and Skinner, "Marking the face." Armando R. Favazza, Bodiesunder Siege: Self-mutilation and Body Modification in Culture and Psychiatry (2nd ed., Baltimore: Johns Hopkins University Press, 1996), explores self-mutilation both as religious practice and as mental illness from antiquity to the modern day.

80. E.g. Practical Medicine from Salerno to the Black Death, ed. Luis Garcia-Ballester, Roger French, Jon Arrizabalaga and Andrew Cunningham (Cambridge: Cambridge University Press, 1994).

81. Horden, "What's wrong?" For Italy, Pilsworth, Healthcare, 74-104, illustrates the value of examining individual, early manuscripts on their own terms.

82. Notably the work of Timothy Miller, The Birth of the Hospital in the Byzantine Empire (Baltimore: Johns Hopkins University Press, 1985); Miller and Nesbitt, Walking Corpses; see also Symposium on Byzantine Medicine: Dumbarton Oaks Papers, 38, ed. John Scarborough (Washington: Dumbarton Oaks Research Library, 1985); Peregrine Horden, "The earliest hospitals in Byzantium, 
western Europe and Islam," Journal of Interdisciplinary History, 35 (2005): 361-389.

83. The Letters of Gerbert with his Papal Privileges as Sylvester II, trans. Harriett Pratt Lattin (New York: Columbia University Press, 1961), 187, Letter 159 (Rheims, I March 989).

84. The classic studies are Charlotte Roberts and Keith Manchester, The Archaeology of Disease, 3rd ed. (Stroud: Sutton, 2005), and Tony Waldron, Palaeopathology (Cambridge: Cambridge University Press, 2008); see also D. J. Ortner, "Human skeletal paleopathology," which inaugurated the International Journal of Paleopathology, l (2011): 4-11.

85. Archaeological examples, several of which either show signs of healing or surgical intervention: E. T. Brødholt and P. Holck, "Skeletal trauma in the burials from the royal church of St Mary in medieval Oslo," International Journal of Osteoarchaeology, 22.2 (2012): 201-18 (undated material); Piers Mitchell et al., "Weapon injuries in the twelfth century crusader garrison of Vadum Iacob castle, Galilee," International Journal of Osteoarchaeology, 16.2 (2006): 145-155; P. Patrick, "Approaches to violent death: a case study from early medieval Cambridge," International Journal of Osteoarchaeology, 16.4 (2006): 347-354; Raphael Panhuysen, "Het scherp van de snede: sporen van geweld in vroegsmiddeleuwse Maastricht," Archeologie in Limburg, 92 (2002): 2-7, where two cases of blade injuries to the skull showed signs of healing. (I thank Professor Panhuysen for assisting me in gaining access to this valuable article.)

86. Willibald Sauerländer, "The fate of the face in medieval art," in Set in Stone: the Face in Medieval Sculpture, ed. Charles T. Little (New York: Metropolitan Museum, 2006), 3.

87. Stephen Parkinson, "Sculpting identity," in Set in Stone, 120-1.

88. As an illustrative example, British Library MS Royal 13 B VIII, f. 30v (late Twelfth -early thirteenth century English compilation) features a crippled man using hand stools.

89. Lepers, whose moral status was ambivalent, are portrayed, however: Christine M. Boeckl, Images of Leprosy: Disease, Religion and Politics in European Art (Kirksville, Missouri: Truman State University Press, 2011). Her examples include the depiction, 32, of Christ healing a leper on the Codex Aureus of St Emmeram, dating to c.870. It is notable that the leper's arms and legs are covered in raised dints to represent the disease, but his face, whilst fashioned with holes and lumps, remains entirely recognizable (ibid., 33). 
90. Umberto Eco, On Beauty, tr. A. McEwan (London: Secker and Warburg, 2004), 111 (Isidore and Thomas); Umberto Eco, On Ugliness (London: Harvill Secker, 2007).

91. Stephen K. Scher, "Iconoclasm: a legacy of violence," in Set in Stone, 20.

92. Antony Eastmond, "Between icon and idol: the uncertainty of imperial images," in Icon and Word, 73-85.

93. Giorgio Agamben, "The face," in id., Means without End: Notes on Politics, tr. V. Binetti and C. Casarino (Minneapolis: Minnesota University Press, 2000) [originally published as Mezzi senza fine (NP: Bollati Boringhieri, 1996)], 91-100; François Delaporte, Anatomy of the Passions, tr. S. Emanuel (Stanford: Stanford University Press, 2008) [originally published as Anatomie des passions (Paris: PUF, 2003)].

94. Stephen Pattison, Saving Face: Enfacement, Shame, Theology (Aldershot: Ashgate, 2013).

95. P. Christopher Earley, Face, Harmony and Social Structure: An Analysis of Organizational Behavior across Cultures (Oxford: Oxford University Press, 1997), offers a useful overview.

96. Groebner, "Losing face, saving face?"

97. Giorgio Agamben, Homo Sacer: Sovereign Power and Bare Life, tr. Daniel Heller-Roazen (Stanford: Stanford University Press, 1998) [Italian publication Torino: Einaudi, 1995].

98. Skinner, "Gendered nose."

99. John Berger, Ways of Seeing (London: Penguin, 1972, repr. 2008); Garland-Thompson, Staring.

Open Access This chapter is distributed under the terms of the Creative Commons Attribution 4.0 International License (http://creativecommons.org/licenses/by/4.0/), which permits use, duplication, adaptation, distribution and reproduction in any medium or format, as long as you give appropriate credit to the original author(s) and the source, provide a link to the Creative Commons license and indicate if changes were made.

The images or other third party material in this book are included in the work's Creative Commons license, unless indicated otherwise in the credit line; if such material is not included in the work's Creative Commons license and the respective action is not permitted by statutory regulation, users will need to obtain permission from the license holder to duplicate, adapt or reproduce the material.

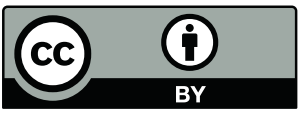

